ks. Henryk Sławiński

Uniwersytet Papieski Jana Pawła II w Krakowie

\title{
Preferencyjna miłość do ubogich w przepowiadaniu Kościoła
}

Zadaniem teologów, a szczególnie teologów pastoralistów i głosicieli słowa Bożego, jest rozpoznawanie znaków czasu'. Niewątpliwym znakiem czasu dla Kościoła Xxi w. jest pontyfikat papieża z Buenos Aires, który jako pierwszy w historii przyjął imię Franciszka Bernardone (1181/2-1226), znanego przede wszystkim ze swego umiłowania ubóstwa ze względu na upodobnienie do Chrystusa ubogiego (por. 2 Kor 8, 9) ${ }^{2}$. Nie oznacza to, że poprzednicy papieża Franciszka na Stolicy Piotrowej nie dostrzegali tego problemu. Przecież Jan Paweł II, na początku trzeciego tysiąclecia chrześcijaństwa w liście apostolskim Mane nobiscum Domine, pisząc w związku z Rokiem Eucharystii (październik 2004 - październik 2005) o problemie ubogich całego świata, o dramacie głodu, o niedostatku bezrobotnych i o nieszczęściach imigrantów, uznał, że są to formy zła nękające także bogate regiony świata. Stwierdził przy tym: „Nie łudźmy się: za prawdziwych uczniów Chrystusa zostaniemy uznani, jeśli będziemy się wzajemnie miłować, a w szczególności, jeżeli otoczymy troską potrzebujących (zob. J 13, 35; Mt 25, 31-46). To właśnie kryterium sprawdzenia autentyczności naszych celebracji liturgicznych"3.

1 Por. Franciszek, adhort. apost. Evangelii gaudium, 24.11.2013, Kraków 2013, 51.

2 Zob. D. Kasprzak, Ubóstwo monastyczne a ubóstwo franciszkańskie - próba zestawienia tez normatywnych, „Polonia Sacra” 20 (2016) nr 1(42), s. 59-79; A. Horowski, Ubóstwo według świętego Bonawentury w Postylli do Ewangelii św. Łukasza, „Polonia Sacra” 20 (2016) nr 1(42), s. 21-37.

3 Jan Paweł II, list apost. Mane nobiscum Domine, 7.10.2004, 28, http://www.opoka.org.pl/ biblioteka/W/wP/jan_pawel_ii/listy/mane_nobiscum_07112004.html, 14.08.2017. 
Podobnie papież Benedykt xvi podkreślał potrzebę troski o ubogich zarówno w związku z liturgią, jak i kościelną posługą słowa. Przepowiadanie słowa Bożego (kerygma) jest bowiem, wraz ze sprawowaniem sakramentów (leiturgia) i posługą miłości (diaconia), jednym z trzech zadań wyrażających wewnętrzną naturę Kościoła. Zadania te tworzą integralną całość. Są one ze sobą powiązane do tego stopnia, że nie można ich od siebie oddzielać4.

Nauczanie Franciszka na ten temat trzeba widzieć w hermeneutyce ciągłości. Podjął on myśl swoich poprzedników i niezwykle wyeksponował fakt, że „ubodzy są uprzywilejowanymi adresatami Ewangelii”. Apelował też o to, by Kościół odszedł od koncentracji na sobie na rzecz „misji skoncentrowanej na Jezusie Chrystusie i zaangażowania na rzecz ubogich”“ oraz „promocji ubogich" , ponieważ ubodzy zajmują preferencyjne miejsce u Boga ${ }^{8}$. Papież Franciszek wskazał związek przepowiadania słowa Bożego z preferencyjną miłość do ubogich i podkreślił, że samo głoszenie Ewangelii jest już pierwszym nakazem miłosierdzia: „Bez opcji preferencyjnej na rzecz ubogich «głoszenie Ewangelii - będące przecież pierwszym nakazem miłosierdzia - może pozostać niezrozumiane i utonąć w powodzi słów, którymi i tak jesteśmy nieustannie zalewani we współczesnym społeczeństwie przez środki przekazu»" 9 .

Celem niniejszego opracowania jest ukazanie miłości do ubogich jako preferencyjnej opcji w przepowiadaniu Kościoła i uzasadnienie jej na przykładzie Pana Jezusa, apostołów i doświadczenia Kościoła w epoce patrystycznej. W związku z tym najpierw zostanie omówiona preferencyjna miłość Jezusa do ubogich, potem apostolska posługa słowa połączona z miłością do ubogich, a następnie miłość do ubogich jako podstawa atrakcyjności chrześcijaństwa dla niechrześcijan. W dalszej kolejności omówione zostaną konstytutywne elementy miłości chrześcijańskiej do ubogich w przepowiadaniu oraz niezbędność głoszenia Chrystusa współczesnym ubogim i wraz z nimi.

4 Por. Benedykt XVI, enc. Deus Caritas est, 25.12.2005, Kraków 2006, 25; Kongregacja ds. Biskupów, dyrektorium Apostolorum Successores o pasterskiej posłudze Biskupów, 22.02.2004, Watykan 2004, nr 2, 118-164, 194.

Franciszek, adhort. apost. Evangelii gaudium, 48.

6 Franciszek, adhort. apost. Evangelii gaudium, 97.

7 Franciszek, adhort. apost. Evangelii gaudium, 187; por. 188; 197-198.

8 Por. Franciszek, adhort. apost. Evangelii gaudium, 197.

9 Por. Franciszek, adhort. apost. Evangelii gaudium, 199. 


\section{Preferencyjna miłość Jezusa do ubogich}

Nieodłącznym elementem przepowiadania Pana Jezusa była troska o słuchaczy, również o ich przyziemne, naturalne potrzeby. Widząc gromadzące się przy Nim tłumy, Jezus litował się nad nimi i uzdrawiał chorych (por. Mt 14, 14). Przykładem Jego troski o słuchaczy słowa Bożego jest wydarzenie nad Jeziorem Galilejskim, dokąd Jezus udał się po uzdrowieniu córki Kananejki z okolic Tyru i Sydonu w południowo-zachodniej części dzisiejszego Libanu. Po przyjściu nad Jezioro Galilejskie Jezus „Wszedł na górę i tam siedział. I przyszły do Niego wielkie tłumy, mając z sobą chromych, ułomnych, niewidomych, niemych i wielu innych, i położyli ich u Jego stóp, a On ich uzdrowił. Tłumy zdumiewały się, widząc, że niemi mówią, ułomni są zdrowi, chromi chodzą, niewidomi widzą. I wielbiły Boga Izraela" (Mt 15, 29b-31). Ubodzy, usłyszawszy o Jezusie i o cudach, których dokonywał, przychodzili do Niego, licząc na to, że i oni doznają Jego cudotwórczej mocy. Wśród wielu słuchaczy Jezusa byli chromi, ułomni, niewidomi, niemowy i inni cierpiący, którzy nawet nie byli w stanie o własnych siłach stanąć przed Jezusem, ale zostali przyniesieni przez innych i położeniu u Jego stóp. Jezus ich nie zawiódł. Ewangelista Mateusz stwierdził aż nadto lakonicznie: „On ich uzdrowił” (Mt 15, 30). Jezus sprowokował także swoich uczniów do troski o to, by nikt z Jego słuchaczy nie był głodny. „Jezus przywołał swoich uczniów i rzekł: Żal Mi tego tłumu! Już trzy dni trwają przy Mnie, a nie mają co jeść. Nie chcę ich puścić zgłodniałych, żeby ktoś nie zasłabł w drodze” (Mt 15, 32). Następnie „polecił tłumowi usiąść na ziemi, wziął siedem chlebów i ryby i odmówiwszy dziękczynienie, połamał, dawał uczniom, uczniowie zaś tłumom. Jedli wszyscy do syta, a pozostałych ułomków zebrano jeszcze siedem pełnych koszów" (Mt 15, 35-37).

Obydwie perykopy - o uzdrowieniu chorych i rozmnożeniu chleba dla słuchaczy Jezusa - ukazują boską tożsamość Jezusa i najgłębszy sens Jego przepowiadania połączonego z preferencyjną miłością wobec ubogich. Jezus uzdrawiał ludzi doświadczających fizycznej niepełnosprawności. Pokazał, że jest zatroskany o usuwanie fizycznego bólu. Dał do zrozumienia, że ci, którzy angażują się w usuwanie lub chociażby pomniejszanie fizycznego cierpienia ludzi, partycypują w Jego misji. Jezus zatroszczył się także o wszystkich zmęczonych. On umacnia zmęczonych podróżą czy pracą; tych, którym słabną nogi, ręce czy oczy. I wreszcie Jezus zaspokoił głód tych, którzy słuchali Jego słowa. Uczynił to, mimo że intencje słuchaczy nie były tak wzniosłe jak samego Jezusa, ponieważ, co odnotował Jan Ewangelista, ludzie podążali za Nim nie dlatego, że widzieli znaki, ale dlatego, że jedli chleb do syta (por. J 6, 26). 
Jezus objawił swoją nieskończoną troskę o ludzi w potrzebie, o ich ciało w nie mniejszym stopniu niż o ich dusze.

Przykład Jezusa pokazuje, że stałym elementem głoszenia Dobrej Nowiny jest troska o niezbędne do życia ludzkie potrzeby. Niekiedy wręcz owa troska wyrażona w spełnianiu uczynków miłosierdzia jest jedynym sposobem głoszenia Ewangelii Chrystusa. Przekonująca siła działalności charytatywnej stanowi paradygmat ewangelizacji, który, za Timothym E. Byerleyem, można nazwać modelem bochenków chleba i ryb ${ }^{10}$.

\section{Apostolska posługa słowa połączona z miłością do ubogich}

Uczniowie Jezusa od samego początku łączyli głoszenie słowa Bożego z opieką nad potrzebującymi - do tego stopnia, że potrzebne okazało się ustanowienie diakonów do posługi wśród potrzebujących. Dzieje Apostolskie relacjonują decyzję apostołów: „ «Nie jest rzeczą słuszną, abyśmy zaniedbywali słowo Boże, a obsługiwali stoły» - powiedziało Dwunastu zwoławszy wszystkich uczniów. «Upatrzcież zatem, bracia, siedmiu mężów spośród siebie, cieszących się dobrą sławą, pełnych Ducha i mądrości! Im zlecimy to zadanie. My zaś oddamy się wyłącznie modlitwie i posłudze słowa»" (Dz 6, 2-4). Chociaż już w czasach apostolskich wyłoniły się stopnie sakramentalnych święceń, nie oznacza to, że diakoni nie głosili słowa, zostawiając to zadanie wyłącznie apostołom, a ci jakoby nie zajmowali się w ogóle potrzebującymi. I apostołowie, i diakoni głosili słowo i otaczali opieką potrzebujących, z tym że inaczej rozłożone były akcenty posługi: priorytetowym zadaniem apostołów jest posługa słowa, a priorytetem diakonów - charytatywna działalność Kościoła.

Miłość do ubogich była nieodłącznym elementem posługi słowa św. Pawła z Tarsu. Apostołowie uznawani za filary Kościoła - Jakub, Piotr i Jan - uznali równorzędność apostolstwa Pawła oraz fakt, że adresatami ich apostolstwa będą obrzezani, natomiast Paweł razem z Barnabą powinni działać wśród pogan (por. $\mathrm{Ga} 2,9$ ). Taki podział wynikał $\mathrm{z}$ właściwego rozeznania domeny apostolstwa odpowiadającej osobistym kwalifikacjom: Piotr, Żyd palestyński, pozostał apostołem Żydów. Paweł zaś jako Żyd z diaspory, pochodzący z Tarsu w dzisiejszej tureckiej Cylicji, a więc z miasta o kulturze helleńskiej, miał skupić się na działaniu wśród pogan. Jedynym warunkiem, który podkreślili

${ }^{10}$ Por. T. E. Byerley, The Great Commission: Models of Evangelization in American Catholicism, New York-Mahwah NJ 2008, s. 105-107. 
apostołowie - filary z Jerozolimy - było to, by Paweł i Barnaba pamiętali o ubogich, co też oni starali się gorliwie czynić (por. Ga 2, 10).

Świadczy o tym chociażby troska o sprawiedliwość społeczną podczas posługi Pawła w Koryncie, w którym nie brakowało zamożnych chrześcijan. Paweł apelował do nich, by pamiętali o biednych, zachowując przy tym rozsądek i sprawiedliwość: „Nie o to bowiem idzie, żeby innym sprawiać ulgę, a sobie utrapienie, lecz żeby była równość. Teraz więc niech wasz dostatek przyjdzie $\mathrm{z}$ pomocą ich potrzebom, aby ich bogactwo było wam pomocą $\mathrm{w}$ waszych niedostatkach i aby nastała równość, jak to jest napisane: Nie miał za wiele ten, kto miał dużo. Nie miał za mało ten, kto miał niewiele" (2 Kor 8, 13-15; por. $\mathrm{Wj} 16,18)$.

Chrześcijanie żyjący w bogatym mieście, Koryncie, woleli, by Paweł był przez nich wynagradzany stałą zapłatą jako nauczyciel filozofii, aniżeli by pracował jako rzemieślnik. Tymczasem Paweł przyjął sposób życia ubogich członków wspólnoty, rzemieślników uznawanych za niższą warstwę społeczną (2 Kor 12, 13; por. 1 Kor 9). Ryzykując pewnego rodzaju alienację względem zamożnych przyjaciół mających wyższy status społeczny od rzemieślników, Paweł uzasadniał wartość zbiórki darów na cele charytatywne (por. 2 Kor 8-9). To był niebagatelny element jego przepowiadania, mający swe uzasadnienie chrystologiczne. Paweł argumentował: „Znacie przecież łaskę Pana naszego, Jezusa Chrystusa, który będąc bogatym, dla was stał się ubogim, aby was ubóstwem swoim ubogacić" (2 Kor 8, 9).

Będąc dobrze wykształconym znawcą Biblii hebrajskiej, Paweł znał nauczanie żydowskich pisarzy mądrościowych, którzy zachęcali swych czytelników do pamięci o niedostatku, gdy sami cieszyli się dobrobytem (Syr 18, 25). Skierowane do bogatych słowa Pawła: „Teraz więc niech wasz dostatek przyjdzie $\mathrm{z}$ pomocą ich potrzebom, aby ich bogactwo było wam pomocą $\mathrm{w}$ waszych niedostatkach i aby nastała równość, jak to jest napisane" $(2$ Kor 8,14$)$ - można uznać za biblijną inspirację dla współczesnych form ubezpieczeń społecznych: wspierając innych, gdy samemu ma się zyski, można liczyć na wsparcie ze strony pozostałych, gdy zajdzie potrzeba. Podobnie jak Bóg troszczył się o naród wybrany wędrujący po pustyni, tak troszczy się o Mistyczne Ciało Chrystusa, aby „Nie miał za wiele ten, kto miał dużo. Nie miał za mało ten, kto miał niewiele" (2 Kor 8, 15; por. Wj 16, 18). Bóg daje całemu Kościołowi tyle, ile potrzeba, ale to zadaniem jego członków jest właściwe rozdzielenie Bożych darów. 


\section{Miłość do ubogich podstawą atrakcyjności chrześcijaństwa dla niechrześcijan}

Inspirowana przez Pana Jezusa i podjęta przez apostołów posługa słowa łączona $\mathrm{z}$ troską o materialny dobrobyt członków wspólnoty chrześcijańskiej znalazła kontynuację w kolejnych epokach życia i działalności Kościoła. Zdaniem papieża Benedykta xvi cesarz Julian Apostata uważał, że najważniejszym powodem popularności „Galilejczyka” w IV w. była charytatywna działalność Kościoła $^{11}$. Wspominając doświadczenie cesarza Juliana Apostaty (†363), papież Benedykt xvi wykazał:

jak bardzo istotna dla Kościoła pierwszych wieków była zorganizowana i praktykowana caritas. Jako sześcioletnie dziecko Julian był świadkiem zabójstwa swego ojca, brata i innych członków rodziny, dokonanego przez straże cesarskiego pałacu; odpowiedzialnością za tę brutalność - słusznie czy nie - obciążył imperatora Konstancjusza, który uważał się za wielkiego chrześcijanina. Z tego powodu wiara chrześcijańska była dla niego raz na zawsze zdyskredytowana. Gdy został imperatorem, zdecydował odnowić pogaństwo, antyczną religię rzymską, reformując ją jednocześnie w taki sposób, aby mogła stać się siłą napędzającą imperium. $\mathrm{W}$ tej perspektywie obficie czerpał inspirację z chrześcijaństwa. Ustanowił hierarchię metropolitów i kapłanów. Kapłani musieli troszczyć się o miłość bogów i bliźniego. W jednym ze swoich listów napisał, że jedyną rzeczą, która trafiała mu do przekonania w chrześcijaństwie, była działalność charytatywna Kościoła. Dla jego nowego pogaństwa było zatem sprawą decydującą przeciwstawić systemowi działalności charytatywnej Kościoła podobną działalność w ramach jego religii. «Galilejczycy» - mówił - w ten sposób zdobyli świat. Trzeba było $\mathrm{z}$ nimi rywalizować, a nawet ich przewyższyć. $\mathrm{W}$ ten sposób imperator potwierdzał, że caritas była decydującą cechą wyróżniającą chrześcijańską wspólnotę Kościoła ${ }^{12}$.

Chrześcijańskiej działalności charytatywnej nie da się sprowadzić do czystej filantropii ${ }^{13}$. Jest ona zawsze łączona ze świadczeniem o Bogu. Jakkolwiek bywają sytuacje, w których nie da się wprost głosić Jezusa Chrystusa. Mając tego

\footnotetext{
A. Dulles, Foreword, [w:] T. E. Byerley, The Great Commission..., dz. cyt., s. XII.

${ }^{12}$ Benedykt Xvi, enc. Deus Caritas est, 24.

${ }^{13}$ Zob. H. Sławiński, Witnesses of God's Love on the Move and through Service, „Flashing Light” 1 (2011) nr 3, s. 5-10.
} 
świadomość, Sobór Watykański II stwierdził: „[...] okoliczności są niekiedy tego rodzaju, że czasowo nie można bezpośrednio i od razu głosić nowiny ewangelicznej; wówczas misjonarze mogą i powinni cierpliwie, roztropnie, a równocześnie $\mathrm{z}$ wielką ufnością dawać choćby tylko świadectwo miłości i dobroci Chrystusowej i w ten sposób torować drogę Panu i w pewien sposób Go uobecniać"14. Chrześcijańska Caritas jest więc zawsze świadectwem o Bogu i wyrazem wewnętrznej natury Kościoła, dlatego nie jest rodzajem opieki społecznej, którą można by scedować na innych. Chrześcijańska działalność charytatywna zawsze w jakiś sposób łączy się z posługą słowa Bożego i prowadzi do szczytu, jakim są sakramenty celebrowane we wspólnocie Kościoła, z Eucharystią na czele ${ }^{15}$.

Specyfiką chrześcijańskiej posługi charytatywnej jest jej uniwersalizm oraz preferencyjna opcja na rzecz braci w wierze. Nie zachodzi tu żadna sprzeczność ani ekskluzywizm, ale raczej logiczny porządek, który odnajdujemy w zachęcie św. Pawła skierowanej do Galatów: „A zatem, dopóki mamy czas, czyńmy dobrze wszystkim, a zwłaszcza naszym braciom w wierze" (Ga 6, 10). W Kościele, który jest Bożą rodziną w świecie, nikt nie powinien cierpieć z braku tego, co konieczne do życia, ale uczniowie Chrystusa powinni być zarazem wrażliwi na pojawiające się spontanicznie życiowe potrzeby ludzi, bez względu na ich przynależność religijną, narodową czy przekonania polityczne ${ }^{16}$.

\section{Konstytutywne elementy miłości chrześcijańskiej do ubogich w przepowiadaniu}

Przepowiadanie słowa Bożego musi w sposób priorytetowy podejmować kwestię miłości chrześcijańskiej do ubogich. A konstytutywnymi elementami chrześcijańskiej działalności charytatywnej, które nie pozwalają sprowadzić jej do zwykłej filantropii, są natychmiastowość, personalizm, działanie osobiste i wspólnotowe oraz uniwersalizm, a także preferencyjna opcja na rzecz ubogich.

Natychmiastowość udzielenia pomocy $w$ konkretnej sytuacji zagrożenia czyjejś egzystencji polega na tym, że bez jakiejkolwiek zwłoki „głodni muszą być nasyceni, nadzy odziani, chorzy leczeni z nadzieją na uzdrowienie,

${ }^{14}$ Sobór Watykański II, dekret Ad gentes divinitus o misyjnej działalności Kościoła, 7.12.1965, AAS 58 (1966), 6; tekst polski w: Sobór Watykański II. Konstytucje, dekrety, deklaracje. Tekst polski, nowe tłumaczenie, Poznań 2002, s. 433-471.

15 Por. Benedykt xvi, enc. Deus Caritas est, 25a.

${ }^{16}$ Por. Benedykt Xvi, enc. Deus Caritas est, 25b. 
więźniowie odwiedzani itd." ${ }^{17}$. Personalizm wyraża się w dostrzeganiu tego, że w działalności charytatywnej chodzi zawsze o człowieka, „a osoby ludzkie zawsze potrzebują czegoś więcej niż technicznie poprawnej opieki. Potrzebują człowieczeństwa. Potrzebują serdecznej uwagi”18. Tym, którzy podejmują działalność charytatywną, oprócz przygotowania profesjonalnego potrzeba także „formacji serca”: „trzeba ich prowadzić ku takiemu spotkaniu z Bogiem w Chrystusie, które by budziło w nich miłość i otwierało ich serca na drugiego, tak aby miłość bliźniego nie była już dla nich przykazaniem nałożonym niejako z zewnątrz, ale konsekwencją wynikającą z ich wiary, która działa przez miłość (por. Ga 5, 6)"'19.

Działanie osobiste chrześcijańskiej Caritas wyraża się w tym, że „Możemy mieć udział w kształtowaniu lepszego świata jedynie wtedy, gdy spełniamy dobro teraz i osobiście, z pasją i wszędzie tam, gdzie możemy, niezależnie od strategii i programów partii”" ${ }^{20}$. Natomiast wspólnotowość polega na łączeniu spontanicznej działalności jednostki ze wspólnotowym działaniem instytucji kościelnych, z programowaniem i przewidywaniem oraz ze współpracą $\mathrm{z}$ różnymi instytucjami i ludźmi dobrej woli ${ }^{21}$.

Z kolei uniwersalizm działalności charytatywnej polega na tym, że jest ona niezależna od jakiejkolwiek ideologii i nie jest narzędziem jakiejkolwiek strategii, ale aktualizacją miłości ${ }^{22}$. Nie jest środkiem do prozelityzmu, czyli do nawracania innych przez wyrafinowaną presję.

Ten, kto praktykuje caritas w imieniu Kościoła, nie będzie nigdy starał się narzucać innym wiary Kościoła. On wie, że miłość w jej czystości i bezinteresowności jest najlepszym świadectwem o Bogu, w którego wierzymy i który zachęca nas do miłowania. Chrześcijanin wie, kiedy jest czas sposobny do mówienia o Bogu, a kiedy jest słuszne zamilknąć i pozwolić mówić jedynie miłości. On wie, że Bóg jest miłością (por. $1 \mathrm{~J} 4,8$ ) i staje się obecny właśnie wtedy, gdy nie robi się nic innego ponad to, że się kocha. On wie [...], że lekceważenie miłości jest lekceważeniem Boga i człowieka, jest pokusą, by nie zważać na Boga. W konsekwencji najlepsza obrona Boga i człowieka polega właśnie na miłości. Jest zadaniem

\footnotetext{
${ }_{7}$ Benedykt Xvi, enc. Deus Caritas est, 31a.

18 Benedykt Xvi, enc. Deus Caritas est, 31a.

19 Benedykt XVI, enc. Deus Caritas est, 31a.

${ }^{20}$ Benedykt Xvi, enc. Deus Caritas est, $31 \mathrm{~b}$.

${ }^{21}$ Por. Benedykt Xvi, enc. Deus Caritas est, $31 \mathrm{~b}$.

${ }^{22}$ Por. Benedykt Xvi, enc. Deus Caritas est, $31 \mathrm{~b}$.
} 
organizacji charytatywnych Kościoła umacnianie tego przekonania w świadomości ich członków, tak by przez ich działanie - tak, jak przez ich mówienie, milczenie i przykład - stawali się wiarygodnymi świadkami Chrystusa ${ }^{23}$.

\section{Niezbędność głoszenia Chrystusa ubogim i z ubogimi}

Widać więc jasno, że chrześcijańska działalność charytatywna nie marginalizuje Boga ani Jezusa Chrystusa, ponieważ często właśnie brak Boga jest najgłębszą przyczyną ludzkiego cierpienia. Świadectwo o Nim wskazuje drogę wyzwolenia. Tak więc chrześcijańska miłość do ubogich jest daleka od prozelityzmu; nigdy nie łączy się z narzucaniem wiary w Boga i w Jezusa Chrystusa. Idzie raczej $\mathrm{w}$ parze $\mathrm{z}$ poszanowaniem wolności sumienia i wyznania oraz z przekonaniem, że „Miłość jest bezinteresowna; nie praktykuje się jej dla osiągnięcia innych celów"24.

Owa chrześcijańska miłość do ubogich została również w naszych czasach uznana za preferencyjną w przepowiadaniu i w duszpasterskiej działalności Kościoła. Biskupi z całego świata zebrani w Rzymie w dniach 5-26 października 2008 r. na xıI Zwyczajnym Zgromadzeniu Ogólnego Synodu Biskupów na temat słowa Bożego w życiu i misji Kościoła często podkreślali, że zarówno przepowiadanie słowa Bożego, jak i całą działalność duszpasterską powinna cechować preferencyjna opcja na rzecz ubogich. „Istotnie, «w pierwszej kolejności mają prawo do orędzia Ewangelii właśnie ubodzy, potrzebujący nie tylko chleba, ale również Słowa życia»"25. Trzeba ponadto docenić fakt, że „sami ubodzy biorą udział w ewangelizacji”" ${ }^{\prime 2}$. Nie można ich zawieść. Głosiciele słowa Bożego powinni uważnie słuchać ubogich, uczyć się od nich, towarzyszyć im w wierze i motywować do kreatywnego podejścia do życia ${ }^{27}$. Preferencyjna opcja na rzecz ubogich w przepowiadaniu dowartościowuje ubogie środki ewangelizacyjne, ich priorytet wobec rozwiniętej i kosztownej technologii dostępnej jedynie dla bogatych.

${ }^{23}$ Benedykt Xvi, enc. Deus Caritas est, 31c.

24 Benedykt Xvi, enc. Deus Caritas est, 31c.

${ }^{25}$ XII Zwyczajne Zgromadzenie Ogólne Synodu Biskupów, Propositio, 11; cyt. za: Benedykt Xvi, adhort. apost. Verbum Domini, 30.09.2010, Kraków 2010, 107; zob. H. Sławiński, Troska Kościoła o poprawe jakości homilii: od synodu o Eucharystii i Sacramentum Caritatis do synodu o słowie Bożym i Verbum Domini, „Colloquia Theologica Ottoniana” (2012) nr 1, s. 37-62.

${ }^{26}$ Benedykt Xvi, adhort. apost. Verbum Domini, 107.

${ }_{27}$ Por. Benedykt XVI, adhort. apost. Verbum Domini, 107. 
Niezbędne jest ponadto wyraźne rozróżnienie ubóstwa z wyboru, które jest cnotą, a więc dobrem domagającym się troskliwej pielęgnacji, od biedy czy wręcz nędzy, która jest następstwem niesprawiedliwego podziału dóbr i skutkuje bezrobociem, głodem, brakiem stałego miejsca zamieszkania. W przepowiadaniu należy podkreślać wartość dążenia do sprawiedliwości społecznej, a zarazem zachęcać do umiaru i powściągliwości w korzystaniu z dobrodziejstw tego świata. Złotym środkiem jest równowaga „między ubóstwem, «które należy wybrać», i ubóstwem, «które trzeba zwalczać»»"

W Orędziu na I Światowy Dzień Ubogich obchodzonym po raz pierwszy 19 listopada 2017 r. papież Franciszek wyraził pragnienie, aby Światowy Dzień Ubogich stał się „tradycją oraz konkretnym wkładem na rzecz ewangelizacji współczesnego świata". W zamiarze papieża dzień ten ma wzmocnić przekonanie wobec tego, że „dzielenie się z biednymi pozwala nam zrozumieć Ewangelię $\mathrm{w}$ najgłębszej jej prawdzie. Biedni nie są problemem, ale zasobem, $\mathrm{z}$ którego możemy zaczerpnąć, aby przyjąć i żyć istotą Ewangelii”’29.

Przede wszystkim zadaniem biskupów jest organizowanie dzieł charytatywnych w taki sposób, by były one ewangelicznym świadectwem, inspirującym ludzi do słuchania słowa Bożego i do nawrócenia serca. Dzieła miłosierdzia świadczone przez wspólnoty chrześcijańskie mają wyrażać nadprzyrodzoną miłość, która je motywuje do składania wyraźnego świadectwa dla chwały Boga, zgodnie z życzeniem Chrystusa: „Tak niech świeci wasze światło przed ludźmi, aby widzieli wasze dobre uczynki i chwalili Ojca waszego, który jest

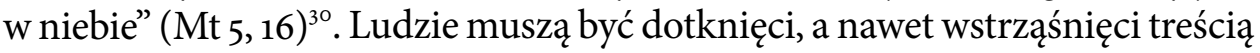
Chrystusowego Kazania na górze i Jego utożsamieniem się z najmniejszymi braćmi (por. Mt 25).

\section{ABStrakt}

Kościół musi rozpoznawać znaki czasu i w związku z nimi realizować swoje zadania wyrażające jego wewnętrzną naturę, a więc przepowiadanie słowa Bożego, sprawowanie sakramentów i posługę miłości. Niewątpliwym znakiem czasu jest pontyfikat

${ }^{28}$ Por. Benedykt xvi, adhort. apost. Verbum Domini, 107.

${ }^{29}$ Franciszek, Orędzie na I Światowy Dzień Ubogich (33 niedziela zwykła w ciagu roku), 19 listopada 2017. Nie miłujmy słowem, ale czynem, 13.06.2017, 9, https://w2.vatican.va/content/ francesco/pl/messages/poveri/documents/papa-francesco_20170613_messaggio-i-giornatamondialepoveri-2017.html, 14.08.2017.

30 Por. Kongregacja ds. Biskupów, dyrektorium Apostolorum Successores, nr 196. 
papieża z Buenos Aires, który przyjmując po raz pierwszy w dziejach papiestwa imię biedaczyny z Asyżu, wskazał priorytet swojego pontyfikatu: preferencyjną miłość do ubogich. Jest to zarazem wskazanie, jaki powinien być priorytet całego Kościoła. W związku z tym na kanwie przykładu Jezusa z Nazaretu, posługi apostołów i doświadczenia Kościoła w czasach patrystycznych omówiony został konieczny związek współczesnej posługi słowa z preferencyjną miłością do ubogich oraz konstytutywne elementy miłości chrześcijańskiej do ubogich, które powinny być częstym tematem $\mathrm{w}$ przepowiadaniu.

\section{SŁOWA KLUCZOWE}

ubodzy, przepowiadanie, Caritas

\section{Abstract}

\section{Preferential love for the poor in the preaching of the Church}

The Church is called to keep on recognizing the signs of the times and, in connection with them, to carry out her intrinsic tasks expressing her inner nature: the proclamation of the word of God, the sacraments and the ministry of charity. The present pontificate is one of the signs of the times and its priority is the preferential love of the poor. This very priority is an indication for the contemporary mission of the Church, especially for her preaching. This paper points out the necessary link between the present ministry of the word, and the preferential love for the poor. The subject is based on the example of Jesus of Nazareth, the ministry of the apostles and the experience of the Church in patristic times. At the end the constitutive elements of Christian love for the poor are discussed. They should be very often present in preaching.

\section{KEY WORDS}

the poor, preaching, Caritas

\section{BIBLIOGRAFIA}

Benedykt XVI, Enc. Deus Caritas est, 25.12.2005, Kraków 2006.

Benedykt XVI, Adhort. apost. Verbum Domini, 30.09.2010, Kraków 2010.

Byerley T. E., The Great Commission: Models of Evangelization in American Catholicism, New York-Mahwah NJ 2008.

Dulles A., Foreword, [w:] T. E. Byerley, The Great Commission: Models of Evangelization in American Catholicism, New York-Mahwah NJ 2008, s. IX-XIII.

Franciszek, Adhort. apost. Evangelii gaudium, 24.11.2013, Kraków 2013. 
Franciszek, Orędzie na I Światowy Dzień Ubogich (33 niedziela zwykła w ciagu roku), 19 listopada 2017. Nie mitujmy stowem, ale czynem, 13.06.2017, https://w2.vatican.va/ content/francesco/pl/messages/poveri/documents/papa-francesco_20170613_messaggio-i-giornatamondiale-poveri-2017.html.

Horowski A., Ubóstwo według świętego Bonawentury w Postylli do Ewangelii św. Łukasza, „Polonia Sacra” 20 (2016) nr 1(42), s. 21-37.

Jan Paweł II, List apost. Mane nobiscum Domine, 7.10.2004, http://www.opoka.org.pl/ biblioteka/W/wP/jan_pawel_ii/listy/mane_nobiscum_07112004.html.

Kasprzak D., Ubóstwo monastyczne a ubóstwo franciszkańskie - próba zestawienia tez normatywnych, „Polonia Sacra” 20 (2016) nr 1(42), s. 59-79.

Kongregacja ds. Biskupów, dyrektorium Apostolorum Successores o pasterskiej posłudze Biskupów, 22.02.2004, Watykan 2004.

Sławiński H., Troska Kościoła o poprawe jakości homilii: od synodu o Eucharystii i Sacramentum Caritatis do synodu o słowie Bożym $i$ Verbum Domini, „Colloquia Theologica Ottoniana" (2012) nr 1, s. 37-62.

Sławiński H., Witnesses of God's Love on the Move and through Service, „Flashing Light" 1 (2011) nr 3, s. 5-10.

Sobór Watykański II, Dekret Ad gentes divinitus o misyjnej działalności Kościoła, 7.12.1965, AAS 58 (1966), s. 947-990; tekst polski w: Sobór Watykański II. Konstytucje, dekrety, deklaracje. Tekst polski, nowe tłumaczenie, Poznań 2002, s. 433-471. 